\title{
PENGARUH KONSUMSI CRACKERS KENTANG HITAM (Coleus tuberosus) KAYA RESISTANT STARCH TIPE 3 TERHADAP PROFIL LIPIDA TIKUS YANG MENDERITA HIPERKOLESTEROLEMIA
}

\section{(THE EFFECT OF COLEUS TUBEROSUS CONTAINING RESISTANT STARCH TYPE 3 CRACKERS ON HYPERCHOLESTEROLEMIA SUFFERING ANIMALS)}

\author{
Mutiara Nugraheni, Siti Hamidah, dan Rizqie Auliana \\ Fakultas Teknik Universitas Negeri Yogyakarta \\ J1. Colombo No. 1 Yogyakarta \\ e-mail: mutiara_nugraheni@uny.ac.id
}

\begin{abstract}
Abstrak
Penelitian ini bertujuan untuk mengetahui pengaruh konsumsi tepung kentang hitam kaya resistant starch tipe 3 dan crackers kentang hitam pada hewan coba terhadap profil lipida pada hewan coba yang menderita hiperkolesterolemia. Metode penelitian dilakukan dengan analisis profile lipida pada hewan coba yang menderita hiperkolesterolemia. Hasil penelitian menunjukkan bahwa konsumsi crackers kentang hitam dan tepung kentang hitam kaya resistant starch sebagai bahan baku pembuatan crackers dapat menurunkan profil lipida (total kolesterol, trigliserida, LDL) dan meningkatkan kadar HDL pada hewan coba hiperkolesterolemia.
\end{abstract}

Kata kunci: hiperkolesterolemia, crackers, kentang hitam, resistant starch

\begin{abstract}
This study was aimed at determining the effect of Coleus tuberosus containing resistant starch type 3 on the hypercholesterolemia suffering animals. The research method used was lipid profile analysis on experimental animals suffering from hypercholesterolemia. The results showed that the consumption of Coleus tuberosus crackers containing resistant starch type 3 as a raw material for making crackers is able to decrease the lipid profile (total cholesterol, triglycerides, $L D L$ ) and increase the HDL level.
\end{abstract}

Keywords: hypercholesterolemia, crackers, Coleus tuberosus, resistant starch

\section{PENDAHULUAN}

Kemajuan sosial ekonomi terhadap suatu daerah dapat menyebabkan beberapa perubahan, salah satunya adalah terjadinya pergeseran pola penyakit, dari penyakit menular ke penyakit degeneratif seperti penyakit hiperkolesterolemia. Hiperkolesterolemia dapat terjadi karena gaya hidup (life style) yang tidak sehat, mulai dari pola makan yang tidak seimbang sampai 
kurangnya aktivitas olah raga. Pola makan tidak seimbang meliputi konsumsi makanan yang tinggi lemak dan karbohidrat, konsumsi makanan yang rendah serat, serta kebiasaan merokok dan juga minum alkohol. Kadar kolesterol yang tinggi di dalam tubuh dapat disebabkan oleh sintesis kolesterol dan penyerapan kolesterol yang tinggi dan juga karena konsumsi makanan yang tinggi lemak dan karbohidrat.

Pati dalam makanan dulu dianggap dapat dicerna secara sempurna. Namun dari beberapa penelitian, ditemukan pati yang lolos pada proses pencernaan usus halus, masuk ke dalam usus besar dan mengalami fermentasi anaerobik dan dikenal sebagai pati resisten. Pati resisten (Resistant Starch/ RS) didefinisikan sebagai pati atau produk degradasi pati yang tidak dapat dicerna oleh usus manusia yang sehat (Asp \& Bjorck, 1992).

Pati resisten, selain mempunyai manfaat yang mirip seperti serat pangan, juga mempunyai kelebihan untuk mencegah kanker kolon dan diare, serta dapat meningkatkan mikroflora usus, sehubungan dengan tingginya kadar asam lemak rantai pendek (Short-Chain Fatty Acid/SCFA) yang merupakan produk akhir utama dari degradasi serat pangan dan RS oleh bakteri anaerob pada usus besar (Cummings, 1989).

Beberapa dasawarsa terakhir ini, RS banyak diteliti terutama dari segi pembentukan dan aspek gizinya. RS dapat dihasilkan dari proses pengolahan (pemanasan dan pendinginan bahan berpati yang berulang-ulang), sifat alami pati (pati kentang, pisang dan bahan nabati tinggi amilosa lainnya) dan sifat fisik bahan berpati (ukuran partikel dan derajat hidrasi) dan sebagainya (Kingman \& Englyst, 1994). Beberapa peneliti menyatakan bahwa pati yang termasuk dalam golongan RS (high amylase corn) mengindikasikan keuntungan pada kesehatan kolon dan manajemen glisemik dan energi. Ada beberapa faktor yang dapat mempengaruhi suatu makanan yang termasuk RS sehingga memiliki sifat hipoglisemik di antaranya adalah rasio amilosa dan amilopektin, retrogradasi amilosa (akibat pengolahan), panjang rantai amilosa. Salah satu tanaman yang diharapkan menjadi sumber RS adalah kentang hitam.

Kentang hitam (Coleus tuberosus) adalah salah satu hasil pertanian di Indonesia sebagai sumber karbohidrat alternatif dan obat-obatan. Kentang hitam memiliki kandungan karbohidrat 33,7 gram per 100 gram, lebih tinggi dari karbohidrat kentang biasa 13,5 gram, juga kandungan energinya dan vitamin C-nya. Selain itu, potensi produktivitas kentang hitam juga tinggi. Di Afrika mencapai 45 ton/ha yang bisa dipanen setiap 4-5 bulan meski di Indonesia produktivitasnya baru 5-15 ton per ha karena teknik budidaya yang belum 
optimal. Selain itu kentang hitam cocok ditanam di dataran rendah, berbeda dengan kentang biasa yang hanya cocok ditanam di dataran tinggi.

Kentang hitam yang merupakan sumber karbohidrat dapat menjadi sumber RS ketika terjadi pengolahan, sehingga dapat menjadi sumber RS tipe 3 . RS tipe 3 dapat mempertahankan karakteristik nutrisi suatu makanan ketika makanan tersebut ditambahkan RS tipe 3. RS tipe 3 juga disukai karena relatif tahan panas dibanding RS tipe lainnya sehingga RS tipe 3 dapat mempertahankan sifatnya selama pengolahan makanan.

RS tipe 3 merupakan tipe RS yang paling banyak digunakan sebagai bahan baku pangan fungsional yang berbasis RS. Kandungan RS tipe 3 dalam makanan secara alami umumnya rendah. Jumlah RS tipe 3 dapat meningkat saat makanan dipanggang atau dalam bentuk pasta dan produk sereal (Shamai, Bianco-Peled, \& Shimoni, 2003). RS tipe ini hanya dapat didispersikan oleh $\mathrm{KOH}$ atau dimetil sulfoksida. RS tipe 3 benarbenar resisten terhadap pencernaan oleh enzim amilase pankreatik (Sajilata, Singhal, \& Kulkarni, 2006). Menurut Edmonton dan Saskatoon (1993), konsentrasi suspensi pati yang dibuat pada awal pembuatan RS tipe 3 mempengaruhi rendemen RS. Pembuatan RS tipe 3 dengan konsentrasi pati 20\% menghasilkan 6-9\% RS.
Beberapa penelitian in vivo yang dilakukan pada hewan dan manusia menunjukkan bahwa RS memiliki potensi sebagai bahan prebiotik. Penelitian dengan menggunakan RS yang beramilosa tinggi menunjukkan bahwa granula-granula pati tersebut membentuk pola pelekatan yang khusus pada usus bagian atas, baik pada usus babi maupun usus manusia, dan diperkirakan dapat meningkatkan viabilitas dari probiotik dengan cara menyediakan permukaan bagi prebiotik untuk melekat (Topping et al., 1997). Penelitian Brown, Wang, Topping, Playne, \& Conway (1998) menunjukkan bahwa tikus yang diberi ransum yang mengandung Bifidobacterium longum hidup dan RS beramilosa tinggi mengekskresikan bifidobakteria dalam jumlah yang lebih banyak daripada tikus yang tidak diberi RS. RS dapat menurunkan kolesterol pada hewan coba yang menderita hiperkolesterolemia. Hal ini sejalan dengan penelitian Vanhoof \& Schrijver (1997) yang menyatakan bahwa pati jagung tinggi amilosa yang telah mengalami retrogradasi dapat menurunkan kondisi hiperkolesterolemia ketika tikus mengkonsumsinya.

Penurunan kolesterol darah ke nilai normal dapat dilakukan dengan dua cara dengan mengurangi konsumsi lemak atau kolesterol yang berasal dari bahan makanan serta menghambat penyerapan kolesterol 
atau menghambat sintesis kolesterol endogen dengan penggunaan obat.

Usaha untuk mengurangi konsumsi lemak dan kolesterol secara ketat tetap tidak menurunkan hiperkolesterol ke keadaan normal pada individu atau usia tertentu. Salah satu upaya menurunkan konsentrasi kolesterol dalam darah yaitu dengan memperbanyak konsumsi serat pangan (dietaryfiber) dan resistant starch. Serat pangan dan resistant starch dapat menghambat absorpsi kolesterol dalam usus halus dan akhirnya akan menurunkan konsentrasi kolesterol dalam plasma serta meningkatkan sintesis kolesterol oleh hati, sintesis empedu, dan ekskresi kolesterol melalui feses. Oleh karena itu, telah banyak digunakan dan direkomendasikan untuk menjaga konsentrasi kolesterol darah supaya tetap normal.

RS yaitu fraksi kecil dari pati yang resisten (tahan) terhadap hidrolisis oleh enzim $\alpha$-amilase dan enzim pululanase yang diberikan secara in vitro. RS tidak terhidrolisis setelah 120 menit inkubasi (Englyst, Kingman, \& Cummings, 1992). Pati yang sampai ke usus besar akan difermentasi oleh mikroflora usus. Oleh karena itu, sekarang RS didefinisikan sebagai fraksi dari pati yang dapat lolos dari pencernaan pada usus halus. Secara kimia, RS adalah selisih dari kadar pati total dengan RDS dan SDS (Sajilata et al., 2006). RS dapat menurunkan kolesterol pada hewan coba yang menderita hiperkolesterolemia. Hal ini sejalan dengan penelitian Vanhoof dan Schrijver (1997) yang menyatakan bahwa pati jagung tinggi amilosa yang telah mengalami retrogradasi dapat menurunkan kondisi hiperkolesterolemia ketika tikus mengkonsumsinya. Tujuan penelitian ini adalah mengetahui pengaruh konsumsi tepung kaya RS tipe 3 dan makanan fungsional berbasis RS tipe 3 terhadap profil lipida hewan coba yang menderita hiperkolesterolemia.

\section{METODE PENELITIAN}

Bahan yang digunakan adalah tepung kentang hitam kaya RS yang dibuat dengan cara kentang hitam yang dikukus selama 30 menit kemudian disimpan dalam refrigerator 24 jam pada suhu $5^{\circ} \mathrm{C}$, dikeringkan dalam cabinet drier suhu $40^{\circ} \mathrm{C}$ selama 24 jam dan digiling, diayak mesh 80. Bahan kedua adalah crackers berbasis tepung kentang hitam tinggi RS. Pakan ketiga adalah pakan standar tikus.

Metode uji aktivitas secara in vivo adalah dengan menyiapkan hewan coba tikus dilakukan di laboratorium Pemeliharaan Hewan Percobaan (UPHP). Dalam hal ini, sebanyak 18 ekor tikus putih jantan jenis wistar dengan berat 110-150 gram dan dikandangkan secara tertutup dengan kondisi kandang seperti cahaya tidak terkontrol, ventilasi udara di dalam kandang cukup, 
temperatur udara pada suhu kamar. Pakan standar diberikan selama tiga hari dengan menggunakan standar AIN 1993 (Reeves, Nielsen, \& Fahey, 1993).

Pakan dibuat pelet kemudian dioven hingga kering dan digunakan sebagai pakan tikus selama 28 hari pemeliharaan. Selanjutnya dilakukan penimbangan berat badan dan pemberian pakan tinggi kolesterol 200 $\mathrm{mg} / \mathrm{kg}$ bb. Tikus tetap diberi pakan standar.

Tikus dibagi dalam tiga kelompok diet yaitu 6 ekor tikus untuk diet standar; 6 ekor tikus untuk diet crackers kaya RS; 6 ekor tikus untuk diet tepung kaya RS tipe 3. Air minum diberikan secara ad libitum. Setiap hari kandang dibersihkan, tempat penampungan kotoran dibersihkan dari kotoran atau feses yang melekat, sisa pakan ditimbang setiap hari. Pakan tikus diberikan setiap pagi hari.

Sampel darah diambil dari mata tikus dan disentrifugasi pada kecepatan $4000 \mathrm{~g}$ (3 menit, $4^{\circ} \mathrm{C}$ ) untuk mendapatkan serum. Serum disimpan pada suhu $-80^{\circ} \mathrm{C}$ sampai lipida serum akan dianalisis. Konsentrasi Total Cholesterol (TC), Total gliserida (TG) dan LD1 dan LDL ditentukan dengan metode kolorimetri enzimatik menggunakan kit komersial (Zou, Ku, \& Wei, 2005).

Data terdiri dari tiga perlakuan dan enam ulangan. Analisis lanjut pengaruh jenis diet terhadap profil lipida dilakukan dengan anava satu jalur.

\section{HASIL DAN PEMBAHASAN}

\section{Konsumsi Pakan}

Konsumsi pakan diamati setiap hari dengan pemberian pakan setiap pagi sebanyak 15 gram. Pakan yang dibuat berdasarkan perlakuan yang ditetapkan diberikan setelah tikus mengkonsumsi pakan tinggi kolesterol dan dinyatakan menderita hiperkolesterolemia. Jumlah asupan pakan standar, tepung kentang hitam kaya RS dan crackers kentang hitam setiap hari sampai 28 hari. Tren konsumsi pakan baik pada pakan standar, tepung kentang hitam kaya RS tipe 3 dan crackers kentang hitam kaya RS tipe 3 menunjukkan bahwa jumlah pakan yang diberikan selalu habis. Hal itu menunjukkan tikus dapat beradaptasi dengan pakan yang diberikan.

\section{Kadar Total kolesterol}

Kolesterol termasuk salah satu sterol yang terdapat pada jaringan hewan. Dalam jaringan, kholesterol terutama berada dalam bentuk bebas (tidak teresterifikasi), juga dapat berikatan kovalen dengan asam lemak sebagai ester kholesterol atau berikatan dengan protein tertentu. Kolesterol bebas merupakan komponen membran sel yang penting dan berperan sebagai prekursor pembentukan asam empedu dan hormon steroid seperti estrogen, testoteron, dan aldosteron. Kadar kholesterol darah yang baik adalah di bawah $200 \mathrm{mg} / \mathrm{dL}$. 
Penyakit hiperkolesterolemia memiliki dampak terhadap metabolism lipida. Salah satu dampaknya adalah terjadi peningkatan kadar profil lipida baik total kolesterol, trigliserida, LDL. Pada penelitian ini diet hewan coba menggunakan pakan standar, tepung kentang hitam kaya RS tipe 3 dan crackers kentang hitam. Setelah diberikan diet tepung kentang hitam kaya RS tipe 3 dan crackers kentang hitam sampai 28 hari menunjukkan bahwa total kolesterol menunjukkan penurunan yang nyata dibandingkan dengan control yang diberi diet standar (pati jagung). Disajikan pada Gambar 1.

Berdasarkan Gambar 1 tikus yang menderita hiperkolesterolemia setelah mengkonsumsi pakan baik standar, pakan tepung kentang hitam kaya RS tipe 3 dan crackers kentang hitam menunjukkan penurunan kadar total kolesterol. Berdasarkan analisis statistik, dapat diketahui bahwa ada perbedaan nyata antara tikus yang diberi diet pakan standar dengan pakan tepung kentang hitam kaya RS tipe 3 dan crackers kentang hitam. Tikus yang diberi diet standar tidak mengalami penurunan kadar total kolesterol serum. Penurunan terjadi pada diet pakan tepung kentang hitam kaya RS tipe 3 dan crackers kentang hitam. Penurunan total kolesterol pada kelompok pakan tepung kentang hitam kaya RS tipe 3 adalah 64,18\% dan pada kelompok pakan crackers kentang hitam adalah 77,04\%.

Hasil penelitian ini sejalan dengan penelitian Han et al. (2004) yang menyatakan bahwa tikus yang diberi pakan RS dari kintoki secara signifikan diketahui

Gambar 1. Profil Total Kolesterol Hewan Coba selama Pemeliharaan 28 Hari

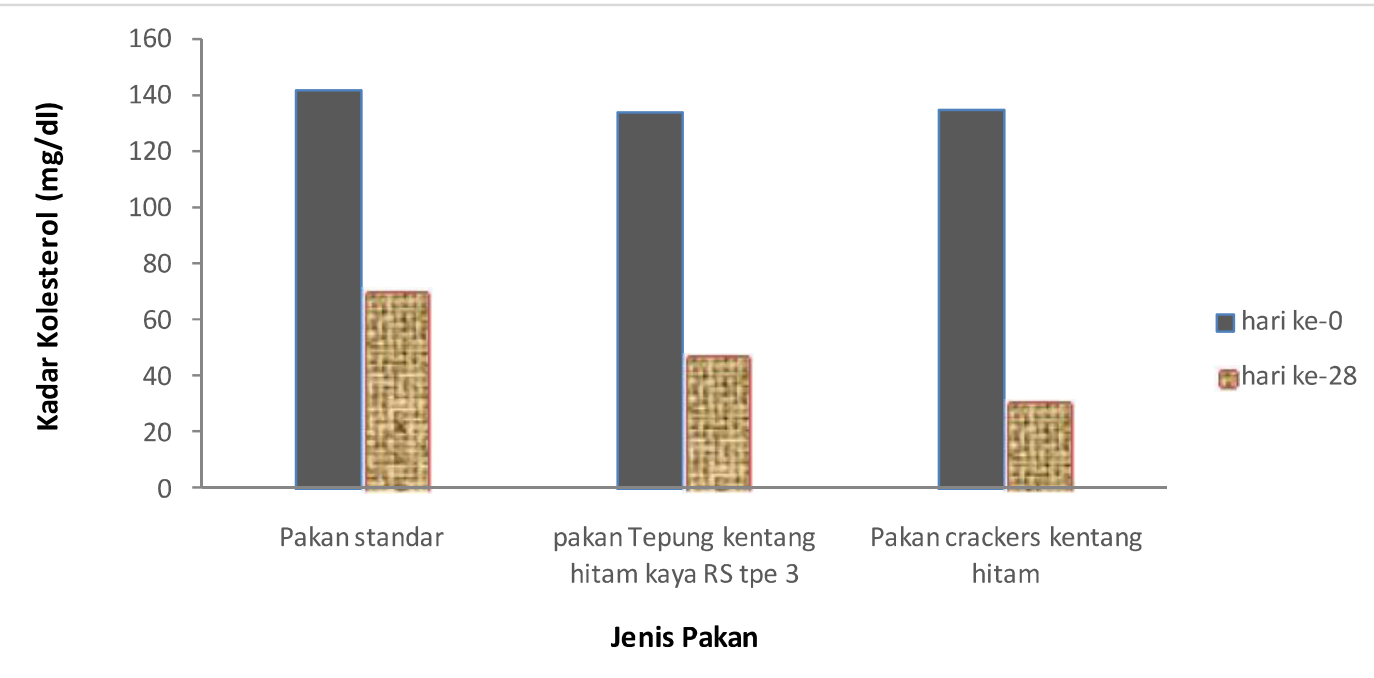


memiliki konsentrasi total kolesterol yang lebih rendah dibandingkan kontrol. Penurunan total kolesterol ini juga diikuti dengan penurunan konsentrasi VLDL, IDL, LDL kolesterol, dan HDL kolesterol. Menurunnya konsentrasi LDL kolesterol dan HDL kolesterol merupakan faktor penting yang dapat menyebabkan menurunnya konsentrasi total kolesterol.

\section{Kadar Trigliserida}

Trigliserida merupakan salah satu bentuk lipida yang terdapat pada darah dan bahan pangan. Trigliserida dihasilkan oleh hati (liver). Profil trigliserida hewan coba disajikan pada Gambar 2.

Tikus yang menderita hiperkolesterolemia setelah pemberian pakan baik standar, pakan tepung kentang hitam kaya RS tipe 3, dan crackers kentang hitam menunjukkan penurunan kadar trigliserida secara signifikan. Tikus yang diberi diet standard tidak mengalami penurunan kadar trigliserida serum, sedangkan penurunan terjadi pada diet tepung kentang hitam kaya RS tipe 3 sebesar $32,90 \%$ dan crackers kentang hitam sebesar 40,20\%.

Penurunan trigliserida berkaitan dengan adanya kandungan RS. Mekanisme RS dalam menurunkan profil lipida adalah RS mengikat asam empedu dan meningkatkan ekskresi asam empedu melalui feses sehingga jumlah asam empedu yang digunakan lebih sedikit. Untuk mengkompensasi ekstresi asam empedu, hati mensitesis asam empedu baru dari kolesetrol dan hal ini mengurangi tingkat kolesterol serum (Bertolotti, Crosignani, \& Del Puppo, 2012) dan RS mengganti pool asam empedu dari cholic acid menjadi chenodeoxycholic acid. Chenodeoxycholic

Gambar 2. Profil Trigliserida Hewan Coba selama Pemeliharaan 28 Hari

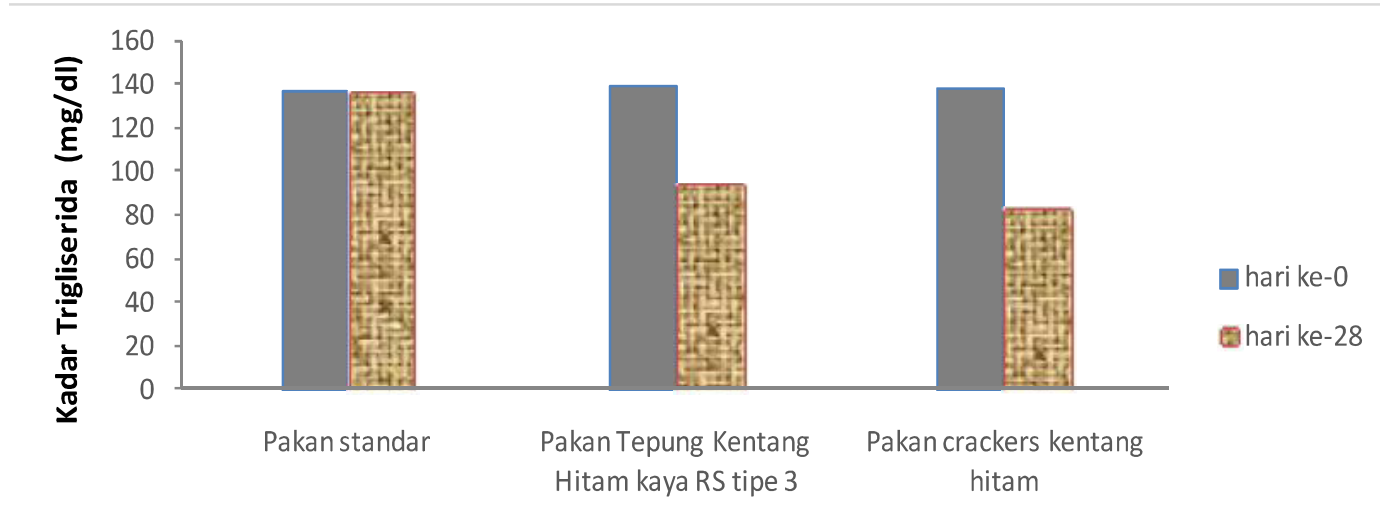

Jenis Pakan 
acid merupakan penghambat dari 3-hydroxy3-methylglutaryl (HMG) CoA reductase, a regulatory enzyme yang diperlukan untuk biosintesis kolesterol. Aktivitas HMG CoA reduktase rendah mengakibatkan produksi kolesterol akan menurun. Dan hal itu menyebabkan kolesterol serum turun.

Damat, Marsono, Haryadi, dan Cahyanto (2008) menyatakan bahwa RS mengikat asam empedu, meningkatkan viskositas isi usus halus sehingga dapat menghambat absorbs berbagai jenis makro-nutrien, termasuk lipida dan mereduksi absornsi asam empedu dari usus halus melalui sirkulasi enterohepatik. Hal itu menyebabkan menurunnya jumlah total kolesterol (TC) yang diikuti dengan penurunan konsentrasi LDL. RS menghambar asam empedu dan steroid netral sehingga asam empedu dan steroid lebih banyak dieksresikan. Han et al. (2005), pakan yang mengandung RS mengingkatkan mRNA hepatic kolesterol 7a-hydroxylase dan meningkatknya asam empedu serta steroid yang diekspresikan bersama feses.

\section{Kadar HDL (High Density Lipoprotein)}

HDL (High Density Lipoprotein) merupakan salah satu lipoprotein yang bertugas mengambil kholesterol dari jaringan ke hati dan membuangnya keluar tubuh. Profil HDL hewan coba disajikan pada Gambar 3.

Tikus yang menderita hiperkolesterolemia setelah pemberian pakan baik standar, pakan tepung kentang hitam kaya RS tipe 3 dan crackers kentang hitam menunjukkan peningkatan kadar HDL secara signifikan. Berdasarkan analisis statistik dapat diketahui bahwa ada perbedaan nyata

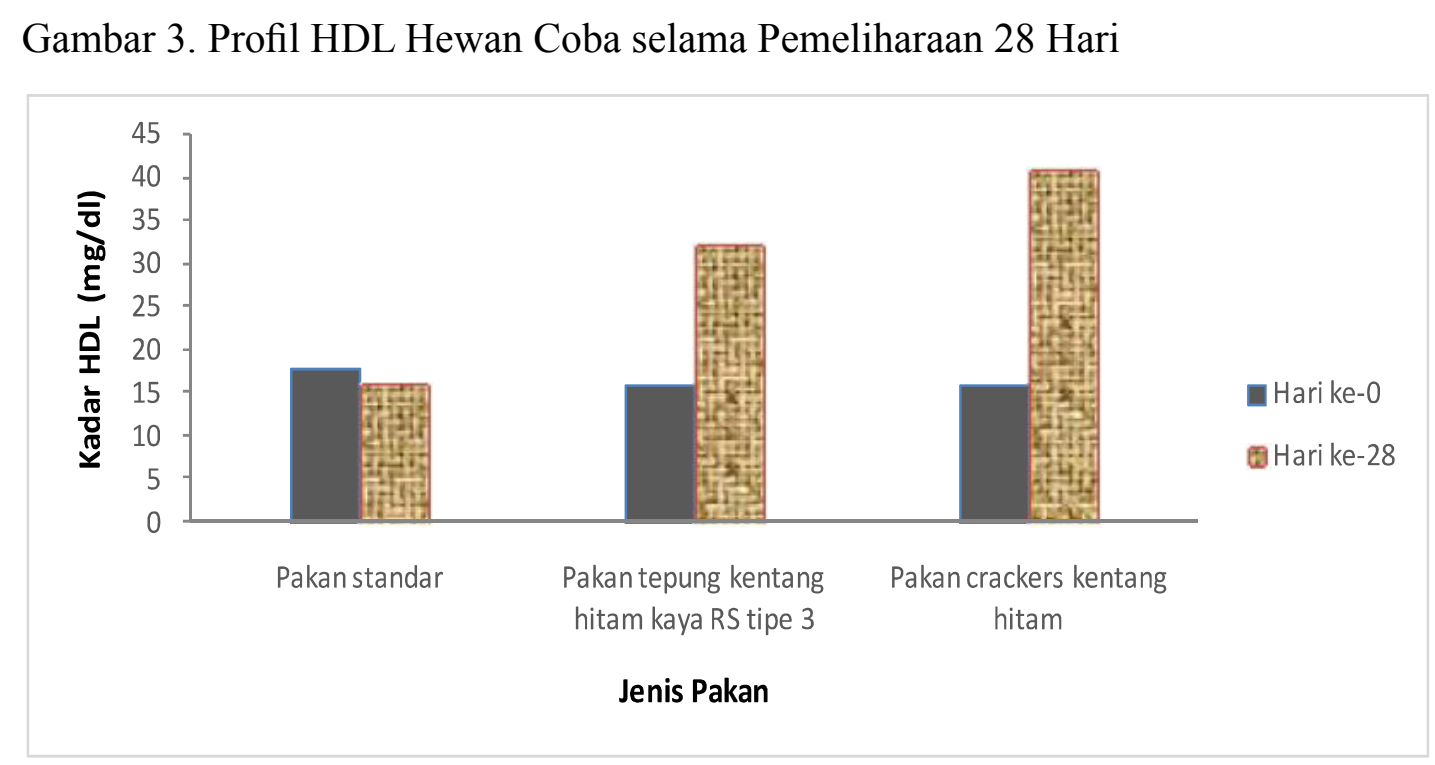


antara tikus yang diberi diet standar dengan tepung kentang hitam kaya RS tipe 3 dan crackers kentang hitam. Peningkatan kadar HDL terjadi pada kelompok pakan tepung kentang hitam kaya RS tipe 3 sebesar $100 \%$ dan pakan crackers kentang hitam sebesar $156 \%$. Namun, pada diet pakan standar mengalami penurunan kadar HDL. Penelitian ini sejalan dengan Bronkowska et al. (2013) yang menunjukkan bahwa diet RS dapat menaikkan kadar HDL. Miao \& Ying-Long (2012) juga memberikan hasil yang sama bahwa konsumsi RS dari ubi jalar dapat meningkatkan kadar HDL pada hewan coba yang mengalami hiperlipidemia.

\section{Kadar LDL (Low Density Lipoprotein)}

\section{LDL (Low Density Lipoprotein)} merupakan salah satu lipoprotein yang bertugas mengangkut kholesterol ke jaringan termasuk arteri. LDL sering disebut sebagai kholesterol jahat. Sebagian besar kholesterol darah berada dalam bentuk LDL. Profil LDL hewan coba disajikan pada Gambar 4.

Pemberian pakan tepung kentang hitam kaya RS tipe 3 dan crackers kentang hitam menunjukkan penurunan kadar LDL. Ada perbedaan nyata antara tikus yang diberi diet standar dengan tepung kentang hitam kaya RS tipe 3 dan crackers kentang hitam. Penurunan kadar LDL terjadi pada kelompok pakan tepung kentang hitam kaya RS tipe 3 sebesar $14,30 \%$ dan pakan crackers kentang hitam sebesar 21\%, sedangkan pakan standar mengalami kenaikan LDL.

Pemberian diet tepung kentang hitam kaya RS tipe 3 dan crackers kentang

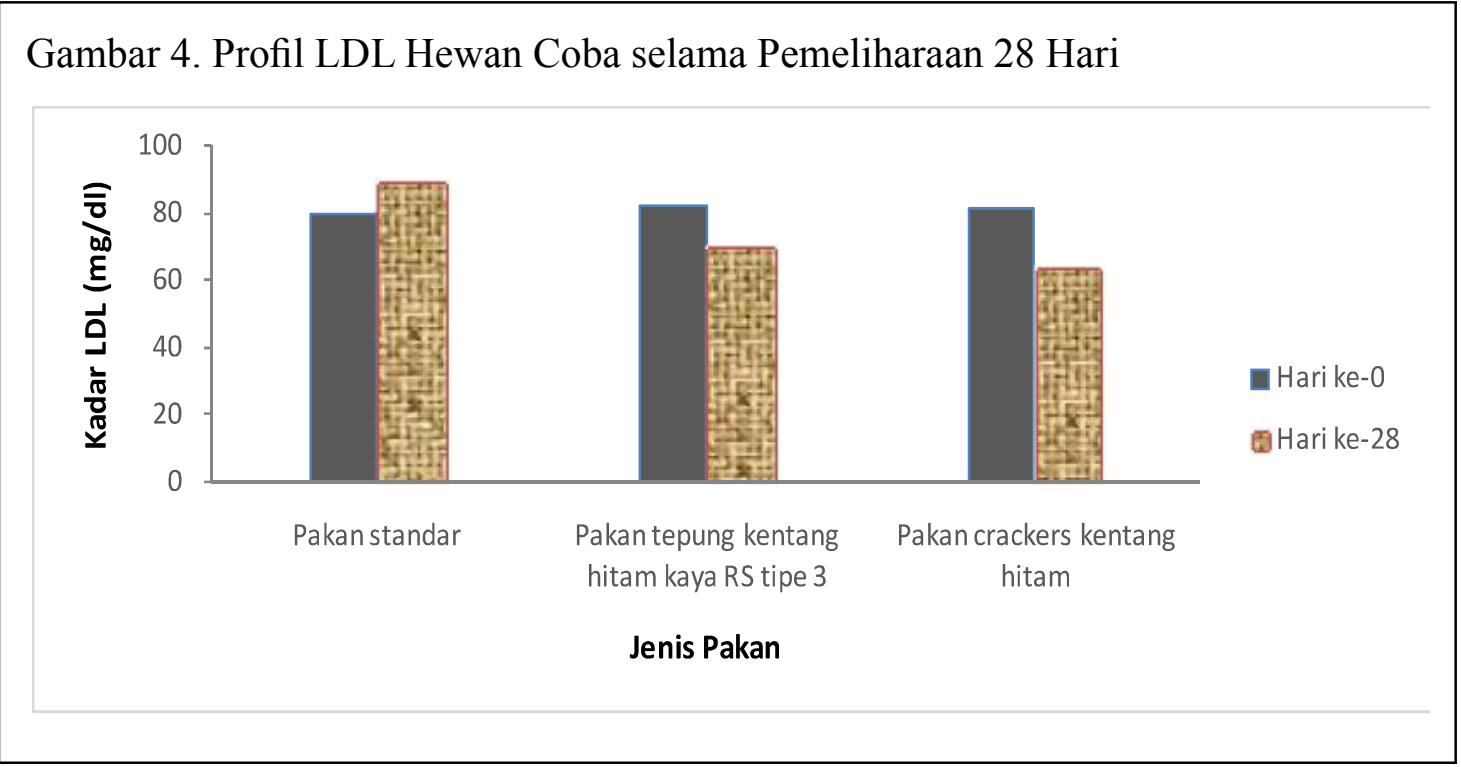


Jurnal Penelitian Saintek, Vol. 21, Nomor 1, April 2016

hitam memberikan dampak yang positif terhadap profil lipida pada tikus yang menderita hiperkolesterolemia. Hal itu dapat diketahui dari tren parameter total kolesetrol (TC), trigliserida (TG), dan LDL yang menunjukkan tren menurun dan mendekati kadar pada tikus yang normal. Parameter HDL menunjukkan peningkatan mendekati kadar HDL normal.

Perbaikan profil lipida pada tikus hiperkolesterolemia berkaitan dengan sifat fungsional dari kentang hitam yang memiliki kandungan RS yang tinggi. Kadar RS pada crackers kentang hitam lebih tinggi dibandingkan bahan bakunya yaitu tepung kentang hitam, hal ini memiliki implikasi pada profil lipida pada hewan coba yang diberi diet makanan tersebut. Hewan coba yang diberi diet dengan pakan crackers kentang hitam memiliki profil lipida yang lebih baik dibandingkan yang diberi diet tepung kentang hitam, sebab RS berperan dalam penurunan kadar total kolesetrol, TG, dan LDL. Hasil penelitian ini sesuai dengan penelitian Han et al. (2005) yang membuktikan bahwa RS dari adzuki memiliki fungsi menurunkan kolesterol melalui peningkatan kadar hepatic $L D L$ receptor $m R N A$ dan cholesterol 7alphahydroxylase $m R N A$ dan eksresi asam empedu feses serta menurunkan kadar hepatic HMGCoA reductase $m R N A$.

\section{SIMPULAN}

Konsumsi tepung kentang hitam kaya RS tipe 3 dan crackers kentang hitam kaya RS tipe 3 dapat memberikan efek positif profil lipida pada hewan coba yang menderita hiperkolesterolemia, tepung kentang hitam dapat menurunkan TC $64,18 \%$; LDL $14,30 \%$; trigliserida $32,90 \%$; dan menaikkan HDL $100 \%$. Crackers kentang hitam dapat menurunkan profil lipida hewan coba, TC 77,04\%; trigliserida 40,20\%; LDL 21\%; dan menaikkkan HDL 156\%.

\section{DAFTAR PUSTAKA}

Asp, N-G, \& Bjorck, I. (1992). Resistant starch a review. Trends in Food Science and Technology, 3, 111-114.

Bertolotti, M., Crosignani, A., Del Puppo, M. (2012). The use of stable and radioactive sterol tracers as a tool to investigate cholesterol degradation to bile acids in humans in vivo. Molecules, 17, 1939-1968.

Bronkowska, M., Orzel, D., Lozna, K., Styczynska, M., Biernat, J., Gryszkin, A., Zieba, T., \& Kapelko, M. (2013). Effect of resistant starch RS4 added to the high-fat diets on selected biochemical parameters in Wistar rats. Rocz Panstw Zakl Hig, 64(1), 19-24.

Brown, I. L., Wang, X., Topping, D. L., Playne, M. J., \& Conway, P. L. (1998). High amylose maize starch as a versatile prebiotic for use with probiotic bacteria. Food Aust., 50, 602-609. 
Cummings, J. H. (1989). Metabolism of dietary fiber in the large intestine. Dalam Cummings, J. H. ( $9^{\text {th }}$ ed.). The role of dietary fiber in enternal nutrition. USA: Abbot International Ltd.

Damat, Marsono, Y., Haryadi, \& Cahyanto, M. N. (2008). Efek hipokolesterolemik dan hipoglikemik pati garut butirat pada tikus Sprague Dawley. Majalah Farmasi Indonesia, 19(3), 109-116.

Edmonton, T. V., \& Saskatoon, R. S. B. (1993). Enhancement of resistant starch (RS3) in amylomaize, barley, field pea and lentil starches. J. Food Chemistry, 4, 527-532.

Englyst H. N., Kingman S. M., \& Cummings J. H. (1992). Classification and measurement of nutritionally important starch fraction. Eur J Clin Nutr, 46, 533-550.

Han, K. H., Sekikawa, M., Shimada, K. I., Sasaki, K., Ohba, K., \& Fukushima, M. (2004). Resistant starch fraction prepared from kintoki bean affects gene expression of genes associated with cholesterol metabolism in rats. Exp Biol Med, 229(8), 787-792.

Han, K. H., Iijuka, M., Shimada, K. I., Sekikawa, M., Kuramochi, K., Ohba, ..., \& Fukushima, M. (2005). Adzuki resistant starch lowered serum cholesterol and hepatic 3-hydroxy3methylglutaryl-CoA mRNA levels and increased hepatic LDL-receptor and cholesterol 7alpha-hydroxylase mRNA levels in rats fed a cholesterol diet. Brit. J. Nutr., 94(6): 902-908.

Kingman, S. M., \& Englyst, H. N. (1994). The influence of food preparation methods on the in vitro digestibility of starch in potatoes. Food Chem., 49, 181-186.
Miao, Y. U., \& Ying-Long, W. U. (2012). Hypolipidemic and liver-benefiting effect of sweet potato resistant starch in hyperlipidemic rats. J. Food Sceince, 33(1), 244-247.

Reeves, P. G., Nielsen, F. H., \& Fahey, G. C.Jr. (1993). AIN-93 purified diets for laboratory rodents: Final report of the American institute of nutrition ad hoc writing committee on the reformulation of the AIN-76A rodent diet. J. Nutr., 123, 1939-1951.

Sajilata, M. G., Singhal, R. S., Kulkarni, P. R. (2006). Resistant starch a review. Food Science and Food safety, 5(1), 1-17. Diunduh dari http://onlinelibrary.wiley. com/doi/10.1111/j.1541-4337.2006. tb00076.x/pdf.

Shamai, K., Bianco-Peled, H., \& Shimoni, E. (2003). Polymorphism of resistant starch type III. Carbohydrate Polymers, 54(3), 363-369.

Topping, D. L., Gooden, J. M., Brown, I. L., Biebrick, D. A., McGrath, L., Trimble, R. P., Choct, M., \& Illman, R. J. (1997). A high amylose (amylomaize) starch raises proximal large bowel starch and increases colon length in pigs. $J$. Nutr. 127, 615-622.

Vanhoof, K., \& Schrijver, R. (1997). Consumption of enzyme resistantstarch and cholesterol metabolism in normoand hypercholesterolemic rats. Nutrition research, 17(8), 1331-1340.

Zou, Y., Lu, Y., \& Wei, D. (2005). Hypocholesterolemic effects of a flavonoid-rich extract of hypericum perforatum L. in rats fed a cholesterolrich diet. Journal of Agricultural and Food Chemistry, 53(7), 2462-2466. 